\title{
Hyperuricemia of Chickens Caused by Inoculation with Nephropathogenic Infectious Bronchitis Virus
}

\author{
Yoshikazu Iritani, Shigemi Aoyama, Kazunari Sawaguchi, \\ Kazumi IwAKI ${ }^{1)}$ and Yukio YoneTANI ${ }^{1)}$ \\ Aburahi Laboratories, Shionogi and Co., Ltd., Koka-cho, Shiga 520-34 \\ ${ }^{1)}$ Discovery Research Laboratories II, Shionogi and Co., Ltd., \\ Futaba-cho, Toyonaka-shi, Osaka 561
}

\begin{abstract}
Hyperuricemia was produced in chickens by artificial infection with nephropathogenic infectious bronchitis virus (IBV) and studied. Typical respiratory symptoms were found in all of the chickens after inoculation with the nephropathogenic AM-83 strain of IBV. Sixteen out of 30 chickens died from 4 to 14 days after challenge. The level of uric acid in plasma was very high at the day before death and the values in the majority of chickens was more than about $100 \mathrm{mg} / \mathrm{d} l$. The chicken surviving against the IBV challenge had hyperuricemia for a longer time than the dead chickens. A few chickens had hyperuricemia for only one day with very low levels of uric acid.

Chickens in contact with the chickens challenged with AM-83 strain of IBV also died of hyperuricemia, but some of them were resistent to the challenge.

We demonstrated that the hyperuricemia in the chickens infected with IBV was divided into the 4 grades of uncertain, mild, moderate and severe.
\end{abstract}

(Jpn. Poult. Sci., $31: 400-406$, 1994)

Key words : hyperuricemia, chicken, infectious bronchitis virus, gout, nephritis

\section{Introduction}

Nephritis and visceral gout are the most common findings during necropsy of chickens in the field. RANDALL et al. (1977) reported that mortality caused by kidney lesion was recorded as $20 \%$ in 2,615 specimens of chickens in laying flocks from the field.

Infectious bronchitis virus (IBV) is distributed worldwide and is a major cause of economic losses to the poultry farms. Infectious bronchitis was first noted as a respiratory disease of young chickens (SCHALK and HAwn, 1931), so, IBV has been considered a prime cause of respiratory disease in chickens. Sine WinterfIELD and HITCHNER (1962) first reported outbreaks of nephrosis by IBV in the United States and Cummings $(1962,1963)$ subsequently reported an IBV outbreaks causing severe kidney lesions in chickens in Australia, nephropathogenic strains of IBV were isolated from commerial chickens with visceral gout (BuTCHER et al., 1988, 1990 ; KINDE et al., 1991 ; SHIMAKURA and HIRAI, 1971). When the nephropathogenic strain was infected artificially to SPF chickens, gross renal lesions such as urate deposition and histologic renal changes were observed in the chickens (Albassam et al., 1988). However, we have little diffinitive knowledge on hyperuricemia of chickens after IBV infection. 
The present study explains the details of hyperuricemia of chickens produced by artificial infection with a nephropathogenic strain of IBV.

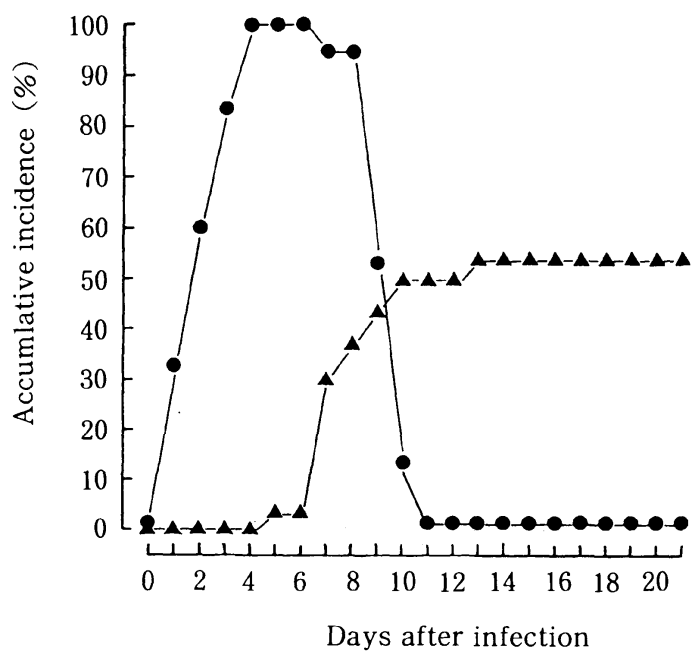

Fig. 1. Incidence of respiratory signs after infection with nephopathogenic IBV and their mortality.

(-) respiratory signs, $(\boldsymbol{\Lambda}-\boldsymbol{\Delta})$ mortality

Table 1. Change of uric acid in dead chickens by artificial challenge with nephropathogenic infectious bronchitis virus

\begin{tabular}{|c|c|c|c|c|c|c|c|c|c|c|c|c|c|c|c|}
\hline \multirow{2}{*}{$\begin{array}{l}\text { Chicken } \\
\text { No. }\end{array}$} & \multicolumn{15}{|c|}{ Days after challenge } \\
\hline & -3 & -1 & 1 & 3 & 4 & 5 & 6 & 7 & 8 & 9 & 10 & 11 & 12 & 13 & 14 \\
\hline 249 & 2.3 & 4.2 & 2.8 & 4.7 & 27.3 & Dead & & & & & & & & & \\
\hline 234 & 5.2 & 4.4 & 3.3 & 4.3 & 3.9 & 7.1 & 53.4 & Dead & & & & & & & \\
\hline 238 & 4.1 & 3.3 & 2.8 & 4.6 & 5.8 & 14.7 & 108.5 & Dead & & & & & & & \\
\hline 240 & 5.9 & 6.0 & 5.2 & 6.1 & 6.7 & 28.1 & 143.8 & Dead & & & & & & & \\
\hline 244 & 1.8 & 3.5 & 3.5 & 4.2 & 2.3 & 7.4 & 174.3 & Dead & & & & & & & \\
\hline 251 & 5.3 & 6.8 & 6.5 & 6.2 & 10.9 & 17.5 & 47.9 & Dead & & & & & & & \\
\hline 255 & 4.1 & 4.3 & 3.2 & 2.3 & 4.1 & 6.5 & 53.2 & Dead & & & & & & & \\
\hline 257 & 5.4 & 5.8 & 3.3 & 4.3 & 5.7 & 4.6 & 35.3 & Dead & & & & & & & \\
\hline 258 & 3.3 & 3.1 & 3.5 & 5.0 & 4.9 & 8.1 & 166.4 & Dead & & & & & & & \\
\hline 239 & 3.3 & 5.0 & 4.1 & 5.6 & 5.3 & 8.6 & 30.3 & 165.2 & Dead & & & & & & \\
\hline 243 & 3.3 & 4.3 & 4.3 & 4.9 & 4.8 & 3.5 & 21.7 & 76.1 & Dead & & & & & & \\
\hline 246 & 2.8 & 4.5 & 2.8 & 3.5 & 2.9 & 3.8 & 4.5 & 12.3 & 151.0 & Dead & & & & & \\
\hline 252 & 3.3 & 7.1 & 4.1 & 5.3 & 6.3 & 4.6 & 12.3 & 54.4 & 133.6 & Dead & & & & & \\
\hline 232 & 2.5 & 4.5 & 3.9 & 3.8 & 5.4 & 3.9 & 4.4 & 6.1 & 12.4 & 219.7 & Dead & & & & \\
\hline 260 & 3.8 & 6.3 & 4.2 & 6.1 & 4.6 & 7.2 & 10.1 & 60.9 & 38.8 & 32.2 & Dead & & & & \\
\hline 248 & 2.9 & 4.6 & 3.4 & 5.4 & 3.4 & 3.4 & 9.0 & 4.8 & 2.6 & 6.6 & 27.5 & 35.7 & 60.5 & 5186.9 & Dead \\
\hline
\end{tabular}

The concentration of uric acid was expressed as $\mathrm{mg} / \mathrm{d} l$. 
Table 2. Trace of uric acid in chickens surving after

\begin{tabular}{|c|c|c|c|c|c|c|c|c|c|c|}
\hline \multirow{2}{*}{$\begin{array}{c}\text { Chicken } \\
\text { No. }\end{array}$} & & & & & & & & & \multicolumn{2}{|c|}{ Days after } \\
\hline & -3 & -1 & 1 & 3 & 4 & 5 & 6 & 7 & 8 & 9 \\
\hline 235 & 3.9 & 4.3 & 4.8 & 4.8 & 5.1 & 4.1 & 6.5 & 8.7 & 7.7 & 8.1 \\
\hline 237 & 2.9 & 3.1 & 2.6 & 4.8 & 3.8 & 4.1 & 6.0 & 4.6 & 3.3 & 10.3 \\
\hline 247 & 3.3 & 3.1 & 3.5 & 4.9 & 5.4 & 4.8 & 5.6 & 5.9 & 7.3 & 6.9 \\
\hline 231 & 5.8 & 6.0 & 5.7 & 5.8 & 5.8 & 7.5 & 9.6 & 15.4 & 16.0 & 12.7 \\
\hline 233 & 2.5 & 3.3 & 3.1 & 4.1 & 3.3 & 2.3 & 3.7 & 3.4 & 1.5 & 5.7 \\
\hline 241 & 3.8 & 5.1 & 4.9 & 5.3 & 4.3 & 5.7 & 11.3 & 11.9 & 4.8 & 9.2 \\
\hline 242 & 2.6 & 3.6 & 4.7 & 5.1 & 3.8 & 5.2 & 6.9 & 6.8 & 10.1 & 42.5 \\
\hline 245 & 2.3 & 3.5 & 3.1 & 5.4 & 13.1 & 22.3 & 22.9 & 50.4 & 22.5 & 24.9 \\
\hline 253 & 2.9 & 6.2 & 5.1 & 4.8 & 4.0 & 6.5 & 6.1 & 7.6 & 26.1 & 22.6 \\
\hline 254 & 3.5 & 3.8 & 4.1 & 2.9 & 6.1 & 4.5 & 9.2 & 5.6 & 7.3 & 6.8 \\
\hline 259 & 3.5 & 5.8 & 3.5 & 5.9 & 3.4 & 9.0 & 14.2 & 6.7 & 8.7 & 8.9 \\
\hline 232 & 3.3 & 4.3 & 5.4 & 5.4 & 4.0 & 4.4 & 6.1 & 7.1 & 5.0 & 7.3 \\
\hline 250 & 2.5 & 5.1 & 2.8 & 5.7 & 8.9 & 9.0 & 8.5 & 7.4 & 7.7 & 9.2 \\
\hline 256 & 2.6 & 4.6 & 4.1 & 3.8 & 3.8 & 4.6 & 4.8 & 4.1 & 4.0 & 3.1 \\
\hline
\end{tabular}

The concentration of uric acid was expressed as $\mathrm{mg} / \mathrm{d} l$.

\section{Materials and Methods}

Virus

A nephropathogenic AM-83 strain of IBV was used. The strain was isolated from a broiler with lesion and gout in kidney at Amori Prefecture in Japan in 1983 (Y ACHIDA et al., 1984). The virus was passaged 3 times in SPF chicken and the kidney was maintained as our stock collection. The virus titer was measured by amnioallantoid inoculation with five 10-day-old embryonated eggs each dilution.

\section{Chicken}

White Leghorn chickens, free from specific pathogens including IBV were used. They were maintained under isolated conditions in our laboratory by ratational crossbreeding without any vaccine (IRITANI and MiYAJIMA, 1979).

Inoculation of IBV

Preliminarily, the nephropathogenicity of a stock collection of AM-83 strain was tested in 4 week old SPF chickens by inoculation to the trachea. The chickens showed respiratory symptoms and diarrhea at 1 day postinoculation and then about half of the chickens died with visceral gout. In this study, IBV was inoculated at the rate of $10^{1.1}$ $\mathrm{EID}_{50} /$ chicken into the trachea of thirty 7-week-old chickens. Five other chickens were placed in the same room as the contact control with inoculated chickens. They were housed in pairs in wire bottomed battery cages. Feed and water were given ad libitum for the experiment. Feed was obtained from a commercial source for layer. Inoculated chickens were observed daily for clinical signs and were autopsied at death and at 22 days post inoculation.

Trace of uric acid levels in plasma

Blood was collected daily at 9 o'clock in the morning from before 3 days until after 
challenge with nephropathogenic infectious bronchitis virus

\begin{tabular}{|c|c|c|c|c|c|c|c|c|c|}
\hline \multicolumn{9}{|c|}{ challenge } & \multirow{2}{*}{$\begin{array}{c}\text { Kidney } \\
\text { lesion }\end{array}$} \\
\hline 10 & 11 & 12 & 13 & 14 & 15 & 18 & 20 & 22 & \\
\hline 7.8 & 6.6 & 3.5 & 4.7 & 5.0 & 5.1 & 5.3 & 6.1 & 6.1 & + \\
\hline 4.3 & 3.9 & 4.4 & 3.4 & 4.3 & 4.2 & 3.3 & 4.3 & 4.3 & - \\
\hline 5.7 & 5.5 & 6.4 & 5.3 & 4.1 & 6.1 & 3.3 & 6.6 & 4.6 & - \\
\hline 10.9 & 7.9 & 7.3 & 5.5 & 7.9 & 10.5 & 5.1 & 11.3 & 4.9 & + \\
\hline 12.0 & 8.6 & 8.0 & 5.8 & 4.2 & 4.6 & 4.8 & 4.1 & 4.1 & - \\
\hline 16.5 & 10.9 & 7.6 & 5.3 & 5.5 & 6.6 & 9.8 & 12.4 & 8.2 & + \\
\hline 19.0 & 9.7 & 6.6 & 5.1 & 4.9 & 5.9 & 5.7 & 6.3 & 5.8 & + \\
\hline 14.1 & 12.2 & 11.4 & 7.1 & 6.1 & 5.6 & 4.4 & 4.6 & 4.1 & - \\
\hline 17.1 & 13.6 & 10.7 & 8.7 & 8.6 & 7.3 & 6.4 & 9.3 & 7.2 & + \\
\hline 5.8 & 5.6 & 5.4 & 7.4 & 5.1 & 3.8 & 8.9 & 6.4 & 5.2 & + \\
\hline 8.6 & 8.9 & 7.4 & 7.3 & 8.6 & 7.5 & 6.6 & 6.5 & 7.1 & + \\
\hline 6.9 & 10.5 & 28.0 & 10.8 & 17.3 & 9.0 & 12.9 & 14.4 & 12.9 & - \\
\hline 12.1 & 11.1 & 9.1 & 12.1 & 8.4 & 40.3 & 9.7 & 11.1 & 11.0 & + \\
\hline 3.9 & 4.7 & 4.7 & 8.0 & 3.5 & 2.8 & 3.8 & 3.8 & 3.8 & + \\
\hline
\end{tabular}

Table 3. Hyperuricemia in contact chickens with artificial infected chickens with nephropathogenic infectious bronchitis virus

\begin{tabular}{|c|c|c|c|c|c|c|c|c|c|c|c|}
\hline \multirow{2}{*}{$\begin{array}{c}\text { Chicken } \\
\text { No. }\end{array}$} & \multicolumn{9}{|c|}{ Days after contact } & \multirow{2}{*}{$\begin{array}{c}\text { Urate } \\
\text { deposition }\end{array}$} & \multirow{2}{*}{$\begin{array}{c}\text { Kidney } \\
\text { lesion }\end{array}$} \\
\hline & 10 & 11 & 12 & 13 & 14 & 16 & 18 & 20 & 22 & & \\
\hline 261 & 3.0 & 6.1 & 4.3 & 11.6 & 174.0 & Dead & & & & + & - \\
\hline 262 & 6.0 & 6.2 & 6.8 & 42.0 & 10.7 & 6.0 & 7.4 & 4.8 & 6.3 & - & + \\
\hline 263 & 4.4 & 4.8 & 4.5 & 4.6 & 4.5 & 4.0 & 3.6 & 4.2 & 3.2 & - & + \\
\hline 264 & 3.8 & 15.6 & Dead & & & & & & & + & - \\
\hline 265 & 4.3 & 5.2 & 3.6 & 3.9 & 3.6 & 10.1 & 5.3 & Dead & & + & + \\
\hline
\end{tabular}

The concentration of uric acid was expressed as $\mathrm{mg} / \mathrm{d} l$.

22 days postinoculation with the nephropathogenic AM-83 strain of IBV. Plasma was obtained from the heparinized blood by centrifugation and then cooled. Uric acid was measured by the uricase-peroxidase method (KABASAKALIAN et al., 1973).

\section{Results}

Some of the chickens inoculated with nephropathogenic AM-83 strain, had respiratory symptoms and a typical diarrhea at the day of postinoculation, and then cumulative incidence of the respiratory symtoms was elevated with rapidity. It reached $100 \%$ at 4 days postinfection. The high incidence lasted for 4 days and then declined. By contrast, the chicken died 5 days postinoculation, there after, the cumulative mortality increased and finally became about $50 \%$. In these dead chicken visceral gout in heart and kidney was found at necropsy.

Table 1 shows the uric acid levels in the plasma of dead chickens before and after infection with AM-83 strain of IBV. The uric acid in the chickens was very low for 3 days before and after inoculation. There was no difference in the concentration of 
uric acid during these 3 days. However, hyperuricemia was found in the chickens after 4 days postinfection. The levels were $27.3 \mathrm{mg} / \mathrm{d} l$ at the lowest and $186.9 \mathrm{mg} / \mathrm{d} l$ at the highest. Morever, before death, a uric acid level of more than $7.2 \mathrm{mg} / \mathrm{d} l$ lasted in 13 of 16 chickens for not more than 5 days and not less than 2 days. In a large majority of the dead chicken, the highest concentration of uric acid was found at the day before death. As a rare case, in chicken No.260 the highest uric acid of $60.9 \mathrm{mg} / \mathrm{d} l$ was detected at 3 days before death, but it was not low at the day before death.

In the chickens surviving the challenge with AM-83 strain of IBV some found kidney lesions were found at necropsy, but a visceral urate deposition was not observed in any of the chicken. Hyperuricemia with more than $7.0 \mathrm{mg} / \mathrm{d} l$ was also found in the surviving chickens. About half of the chickens had hyperuricemia for more than 4 days. Chicken No. 250, had hyperuricemia for the longest duration of 19 days. The hyperuricemia in chicken No. 254 was transient and a few chickens such as chicken No. 237 only showed hyperuricemia for 1 day. A high uric acid of more than $26 \mathrm{mg} / \mathrm{d} l$ was also measured in the plasma of 5 surviving chickens after resistance to infection. These chickens did not die in spite of the same high levels of uric acid as in dead chickens shown in chick No. 249 and 243.

The value of uric acid in chicken in contact with infected chicken at challenge room was 3.8 and $4.3 \mathrm{mg} / \mathrm{d} l$ on the average before for 3 days and after 9 days contacts, respectively. There were no chickens with a value of more than $7.0 \mathrm{mg} / \mathrm{d} l$ during these periods. However, 3 chickens died of hyperuricemia from 11 days after the contact. Deposites of urea and lesions in the kidney were observed at necropsy. In 2 other chickens, hyperuricemia was found in one but not in the other. However, both chickens had kidney lesions without urate deposition at necropsy.

\section{Discussion}

Visceral urate deposition is generally due to a failure of urinary excretion. WiNTERFIELD and HitCHNER (1962) first reported that gross kidney lesions, swelling paleness and degenerative changes were seen by artificial inoculation of IBV into chickens. AlbasSAm et al. (1988) reported that nephropathogenic strains of IBV produced acute renal changes consisting of tubular damage and interstitial inflammatory cell infiltration and edema. Recently, outbreaks of very virulent nephropathogenic IBV were found in commercial farms (BUTCHER et al., 1990 ; Cowen et al., 1987 ; KINDE et al., 1991).

By contrast, these reports did not describe the uric acid in plasma. Studies on uric acid in contacted or inoculated chickens by IBV have only been conducted by NEwTON and Simmons (1963). In the present study, we enhanced the change of uric acid caused by IBV infection. It is an interesting and reasonable fact that the levels of uric acid in dead chickens by IBV challenge were very high at the day before death and the values in the major chickens were more than about 20 times before challenge. Chicken No. 249 died even though the value of uric acid was lower than that of other dead chickens. The time of sampling until death was loger than other dead chickens. Hyperuricemia occurred by IBV challenge and lasted for several days in the dead and surviving 
chickens. Therefore, it may be useful as a screening model to develop a drug for human hyperuricemia. The values of uric acid in both chickens were much higher than that reported by NEwTON and SimMONS (1963), it must be caused by a difference in the pathogenicity to chickens among the IBV strains used. It may be also supported by the fact that dead chickens were also found among those in contact with the chicken artificially inoculated with IBV. The chickens surviving the IBV challenge had kidney lesions at necrospsy but not some of them. A favorable turn may occur in the chickens with mild hyperuricemia because the absence of a kidney lesion.

From present study, we divided the hyperuricemia caused by IBV challenge into the 4 grades of uncertain, mild, moderate and severe. The duration of hyperuricemia and value of uric acid were short and low in the uncertain group of chickens. Further studies are necessary. However, we believe that the biochemical data obtained in the present study may be useful for clinical diagnosis at the field.

\section{References}

Albassam, M.A., R.W. Winterfield and H.L. Thacker (1988) Comparison of the nephropathogenicity of four strains of infectious bronchitis virus. Avian Diseases, 30 : 468-476.

ButcheR, G.D., R.W. WiNTERFIELD and D.P. ShAPIRo (1989) An outbreak of nephropathogenic H13 infectious bronchitis in commercial broilers. Avian Diseases, $33:$ 823-826.

Butcher, G.D., R.W. Winterfield and D.P. Shapiro (1990) Pathogenesis of H13 nephrophathogenic infectious bronchitis virus. Avian Diseases, 34 : 916-921.

Cummings, E.B. (1962) The etiology of uraemia of chickens. Australian Veterinary Journal, $38: 554$.

Cummings, R.B. (1963) Infectious avian nephrosis in Australia. Australian Veterinary Journal, 39 : $145-147$.

Cowen, B.S., R.F. Wideman, H. Rothenbacher and M.O. Braune (1987) An outbreak of avian urolithasis on a large commercial egg farm. Avian Diseases, 31 392-397.

IRITANI, Y. and M. MiYAJIMA (1979) Difference of chicken red blood cells in susceptibility to Haemophilus paragallinarum hemagglutinin. Japanese Journal of Veterinary Science, 41 : 401 -403. 1979.

Kabasakalian, P., S. Kalliney and A. Westcott (1973) Determination of uric acid in serum, with use of uricase and a tribromphenol-aminoantipyrine chromogen. Clinical Chemistry, 19 : 522524.

Kinde, H., B.M. Daft, A.E. Castro, A.A. Bickford, Gelf, Jr. and B. Reynolds (1991) Viral pathogenesis of a nephrotropic infectious bronchitis virus isolated from commercial pullets. Avian Diseases, $35:$ 415-421.

NEWTon, G.L. and G.C. Simmons (1963) A vian nephritis and uraemia. Australian Veterinary Journal, 39 : 135-139.

Randall, C.J., T.B. Blandford, E.D. Borland, N.H. Brooksbank, S.A. Hall, C.N. HeberT and S.R. Richards (1977) A survey of mortality in 51 caged laying flocks. Avian Pathology, 6 : 146-170.

SCHALK, A.F. and M.C. HAWN (1931) An apparently new respiratory disease of baby chick. Journal of American Veterinary Medical Association, 78 : 418-422.

SHImAKURA, H. and K. HiRA (1971) Incidence of avian nephrosis in Japan with special reference to isolation and transmission tests of infective agents. Japanese Journal of Veterinary Science, $33: 206-208$.

WiNTERFIELD, R.W. and M.A. Albassam (1985) Nephropathogenicity of infectious bronchitis virus. Poultry Science, $64: 65-70$.

WINTERFIELD, R.W. and S.B. HitchNER (1962) Etiology of an infectious nephritis-nephrosis syndrome of chickens. American Journal of Veterinary Research, 23 : 1273-1279.

Yachida, S., S. Aoyama, N. Takahashi, K. Sawaguchi, E. Kuwahara, N. Horita, Y. Iritani and Y. HAYASHI (1984) Relation between serum antibody titers and protection in chickens vaccinated 
with infectious bronchitis. Journal of the Japanese Society on Poulty Diseases, 20 : 132-142. (In Japanese)

\title{
腎炎型鶏伝染性気管支炎ウイルス接種により \\ 引き起こされる鶏の高尿酸血症
}

\author{
入谷好一・青山茂美・澤口和成・岩木一巳 ${ }^{1)} \cdot$ 米谷行男 ${ }^{1)}$ \\ 塩野義製薬株式会社 油日ラボラトリーズ \\ 滋賀県甲賀郡甲賀町五反田 1405 520-34 \\ 1) 塩野義製薬株式会社 創薬第 2 研究所 \\ 豊中市二葉町 3 丁目 1-1 561
}

腎炎型鶏伝染性気管支炎ウイルス（IBV）AM-83 株 を, 人為的に 7 週齢 SPF 鵎に接種し, 高尿酸血症を引き 起こし，その血清尿酸值を追跡した。AM-83 株接種鶏 は, 接種 1 日目より呼吸器症状, 下痢などの臨床症状が 認められ，発症率は 4 日目で 100\%となり，7 日目以降 から減少した。一方, 死亡鶏は 5 日目より出現し, 累積 死亡率は約 $50 \%$ に達し, 全死亡例に実質蔵器の尿酸沈 着を認めた。死亡䊿において, 血清尿酸值は大部分が死 亡前日が最も高く，その值は $100 \mathrm{mg} / \mathrm{d} l$ 以上を示した。 尿酸血症の持続は死亡鷄よりも生存鶏の方が長い傾向に
あった。生存鶏における持続性は連続的または，間歇的 であり一過性のものは少なかった。IBV 感染䳕と同室に 飼育された同居鶏にも同様の高尿酸血症と死亡鵎を認め た。今回の成績から，IBV によって惹起される高尿酸血 症を軽度 (一過性), 軽度 (持続性), 中度 (持続性) お よび重度（死亡）の 4 群に区別した。

（家禽会誌，31：400-406，1994） キーワード : 高尿酸血症, ニワトリ, 鶏伝染性気管支炎 ウイルス, 痛風, 腎炎 